\title{
LIBERTY'S DAWN
}





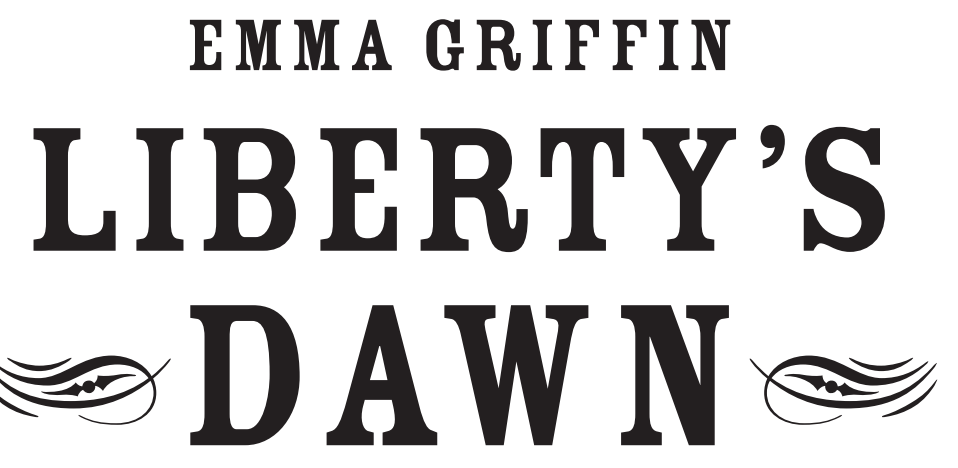

A PEOPLE'S HISTORY of the

INDUSTRIAL

REVOLUTION 


\section{Copyright (C) 2013 Emma Griffin}

All rights reserved. This book may not be reproduced in whole or in part, in any form (beyond that copying permitted by Sections 107 and 108 of the U.S. Copyright Law and except by reviewers for the public press) without written permission from the publishers.

For information about this and other Yale University Press publications, please contact: U.S. Office: sales.press@yale.edu www.yalebooks.com Europe Office: sales@yaleup.co.uk www.yalebooks.co.uk

Set in Adobe Caslon Pro by IDSUK (DataConnection) Ltd Printed in Great Britain by TJ International Ltd, Padstow, Cornwall

Library of Congress Cataloging-in-Publication Data

Griffin, Emma.

Liberty's dawn: a people's history of the Industrial Revolution/Emma Griffin. pages $\mathrm{cm}$

ISBN978-0-300-15180-0 (hardback)

1. Industrial revolution-Great Britain. 2. Great Britain-Social conditions. 3. Great Britain-Economic conditions. I. Title.

HC253.G75 2013

330.941'07-dc23

A catalogue record for this book is available from the British Library. 
For David, Benedict and Anna 
An ample theme: the intense interests, passions, and strategy that throb through the commonest lives.

-Thomas Hardy, The Life and Work of Thomas Hardy, ed. Michael Millgate (London, 1884), p. 158

The most remarkable century ever known in the history of the World, for progress in Education, inventions, Engineering, Electricity, Farming, everything tending to the betterment of the Nation and the Welfare of the People and making life worth living.

—Richard Cook, p. 26, Lincoln Reference Library 